КЛЮЕВА Ирина Васильевна кандидат философских наук, доцент кафедры культурологии и библиотечно-информационных ресурсов Национального исследовательского Мордовского государственного университета имени Н. П. Огарева, Саранск, Российская Федерация Irina V. KLYUEVA

Cand. Sci. (Aesthetics), Assoc. Prof., Ogarev Mordovia State University, Saransk, Russian Federation, klyueva_irina@mail.ru ORCID: 0000-0002-0392-3228

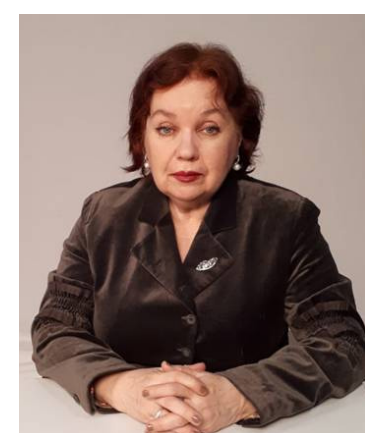

УДК [792.8:929]:73.027.1

DOI: 10.36343/SB.2020.22.2.011

ГРНТИ 18.31.04

BAK 24.00.01

Балерина Софья Федорова 2-я в русской скульптуре

Серебряного века (С. Д. Эрьзя, М.Д.Рындзюнская, Н. Я. Данько)
Ballerina Sofia Fedorova II in the Russian Sculpture of the Silver Age (Stepan Erzia, Marina Ryndzyunskaya, Natalya Danko)

Цель статьи - культурологический и искусствоведческий анализ трех портретных изображений выдающейся балерины Серебряного века русской культуры Софьи Федоровой 2-й (1879-1963), созданных С.Д. Эрьзей, М.Д. Рындзюнской и Н.Я. Данько. Материалом исследования являются архивные документы, отечественная периодика 1910-х гг., отзывы критиков и воспоминания современников о балерине. На основе использования сравнительно-исторического, биографического и семиотического методов представлена характеристика личности и творчества Федоровой 2-й, реконструирована ее биография; прослежена история создания трех скульптур, выявлены их художественные особенности и смысловое наполнение. Автор заключает, что Н. Я. Данько и М.Д. Рындзюнская изображают «дневную» Федорову, главным в их работах является демонстрация красоты и выразительности движений балерины. С.Д. Эрьзя запечатлел «ночную» Федорову: сосредоточив внимание на лице артистки, он сумел в своей скульптуре отразить ее сложный внутренний мир.

Ключевые слова: С. В. Федорова 2-я, Серебряный век, балет, русская скульптура, С. Д. Эрьзя, М. Д. Рындзюнская, Н. Я. Данько.

Софья Васильевна Федорова, известная по сцене как Федорова 2-я (1879-1963) одна из самых ярких звезд русского балета первой трети XX в., составивших его миро- вую славу. Еще в 1914 г., на взлете ее артистической карьеры вышел в свет отдельным изданием очерк С. Григорова «Балетное искусство и С. В. Федорова 2-я» [8]. Творчеству 
и судьбе балерины посвящены страницы в книгах В. М. Красовской по истории русского балета $[10,11]$. Без статьи о ней не обходится сегодня ни одна балетная или театральная энциклопедия.

По свидетельству современника - литературоведа А.В.Чичерина, автор книги о Федоровой - Сергей Николаевич Григоров, студент, «вечно погруженный в журнал “Вопросы философии”», говорил, что для него Федорова 2-я — «то же, что Пушкин или Кант, Рембрандт или Вагнер!.. Ее искусство выражает самые высокие, самые тонкие чувства, столь же чистые, как та музыка, в которой она движется и живет» [29, с. 310, 312].

Мэтр русского символизма Вячеслав Иванов писал о ней: «У Федоровой два лика. Один внешний, часто повторяющийся в ее выступлениях... Это Федорова скачущая, необычайно экспрессивная — в танцах египетских, индийских, цыганских, испанских. Но... это не настоящая Федорова... Дневная Федорова, скрывающая свою тайну. Есть другая Федорова. Почти неподвижная, как бы дремлющая. Но там, в глубине, всплывают какие-то зарницы, молнии пробегают во мраке... Всем своим обликом она будит смутное, тайное воспоминание... Связанные стихии, скрытые обычной жизнью, умеет развязывать эта заклинательница. Ее область - темная мистика души» [9].

Действительно, Федорова известна, прежде всего, как непревзойденная исполнительница характерных танцев (русских, украинских, цыганских, кавказских, испанских, венгерских, индусских и др.) в балетных и оперных спектаклях. Однако «подлинная», «ночная» Федорова заявила о себе в новаторских спектаклях гениев русского балета А.А. Горского (Эсмеральда в «Дочери Гудулы» (1902), Хита в «Дочери фараона» (1905), жрица Молоха в «Саламбо» (1910), главная партия в «Жизели» (1913) и др.) и М. М. Фокина (половецкая девушка в «Половецких плясках» (1909), танцевальный дивертисмент в «Вакханалии» (1909), Таор в «Клеопатре» (1913) и др.).

Имевшая цыганские корни Федорова в 1899 г. окончила балетное отделение Московского театрального училища и сразу была принята в корифейки Большого театра [20, л.
2] (получив вскоре сценическое имя «Федорова 2-я», поскольку танцовщица Федорова уже была в составе труппы - в кордебалете). На нее сразу обратил внимание главный постановщик театра Горский, который перевел ее во второй разряд танцовщиц [20, л. 6]. В 1900 г. Горский вводит для нее, вносившей, по словам Е. Суриц, в любую пляску, «какое-то особое буйство и почти трагический надрыв» [26, с. 14], партию Уличной танцовщицы, исполняющей испанский танец. В начале декабря 1900 г., когда должна была состояться премьера «Дон Кихота», внезапно заболела корифейка Екатерина Гельцер, исполнявшая главную партию - Мерседес. Софья Федорова, заменила ее и спасла спектакль, заставив при этом говорить о себе «всю Москву». Красовская пишет, что обе ее героини «внесли терпкий диссонанс в жизнерадостный поток событий “Дон Кихота”, противопоставляя веселью толпы «гордое одиночество и самосжигающую страсть» [11, с. 151]. Так уже в первых сольных партиях начинающая артистка громко заявила о своей неповторимой индивидуальности, о собственной теме в искусстве.

7 декабря Горский направляет рапорт в Московскую контору императорских театров: Федорова заменила Гельцер «настолько успешно, что танец Мерседес был по требованию публики повторен» [20, л. 7]. Директор императорских театров В.А. Теляковский объявляет Федоровой благодарность [20, л. 7], в январе ее переводят в первый разряд танцовщиц [20, л. 10]. С этого момента началась ее карьера характерной танцовщицы.

Вскоре Федорова становится примой Горский стал поручать ей ведущие партии в своих спектаклях. В 1901 г. он поставил для нее миниатюру «Танец Анитры» на музыку Э. Грига, сделал новую версию партии жены Хана в балете «Конек-Горбунок» Ц. Пуни. Концертмейстер Большого театра Н. Клименкова вспоминала об этом спектакле: «... Софья Федорова. Вот артистка, которую Москва обожала. Она замечательно танцевала... восточный танец на музыку Глазунова... великолепно разыгрывала все мизансцены... танцевала с почти экстатической увлеченностью цыганский танец на музыку Брамса. Позднее он был заменен татарским с луком» 
[цит. по: 2, с. 215-217]. О татарском танце вспоминала другая современница - М. Горшкова: «Буйный татарский танец в исполнении С. В. Федоровой 2-й с ее зажигающей дикостью был просто шедевр...» [цит. по: 2, с. 206].

27 марта 1902 г. Теляковский, присутствовавший на занятиях танцевального класса Горского, записывает: «Конечно, между всеми выделялась Федорова 2-я» [27, с. 216].

В 1902 г. Горский ставит один из самых знаменитых своих спектаклей — «Дочь Гудулы» - мимодраму на музыку А. Симона по мотивам романа В. Гюго «Собор Парижской Богоматери». Пресса обвиняла балетмейстера в излишнем натурализме. (Горский сделал главным героем своего спектакля средневековый Париж - с его «двором чудес» и пестрой толпой, нищими, калеками...) Известный критик Ю. Беляев назвал свою рецензию «Балет или каторга?»[3]. Но многим выдающимся деятелям театрального искусства, например, К.С.Станиславскому, спектакль понравился. Софья Федорова выступила в партии Эсмеральды. Даже Беляев, в целом негативно оценивший спектакль, высоко отзывался о ее игре, особенно в сцене покаяния Эсмеральды у собора [3].

Актриса С. В. Гиацинтова, маленькой девочкой увидевшая Софью Федорову в этом спектакле, писала в своей книге: «Юная цыганка в исполнении Федоровой 2-й, маленькой балерины с большим темпераментом, привела меня в неистовство. Я просто заболела балетом...» [5, с. 474]. В журнальной публикации она снова вспоминала о своем детском впечатлении: «В миниатюрной балерине было что-то значительное, притягательно-прекрасное... покоряло "самовыражение" страстного, бурного и вместе с тем необыкновенно поэтичного существа...» [6].

В 1904 г. танцовщица выступает в балете Минкуса «Баядерка», в 1905 г. исполняет роль Лизы в «Тщетной предосторожности» П. Гертеля. В этом же году она впервые встретилась на сцене с Анной Павловой - в спектакле «Дочь фараона» (муз. Ц. Пуни). Павлова, специально приезжавшая из Петербурга, исполняла роль Бинт-Анты, Федорова - ее рабыни Хиты. Красовская пишет о созданном ею образе: «Сутулая, с лицом страдальчески надменным, все более бледневшим по мере того, как разгорался, расширялся немигающий взор из-под насупленных бровей... Для этой танец... таинство, но не светлое, а какое-то недоброе, дикое» [10, с. 82].

Для Горского Федорова воплощала идеал артистки балета. Новатору русского балета нужны были не балерины, а танцующие актрисы, которые танцевали бы не «ногами», а всем телом, руками, корпусом, лицом, душой. Достижение художественной правды хореографического образа для него было важнее безупречности технической подготовки. Об этом писал Григоров: «Танец одними ногами теперь почти совсем отошел в прошлое. Но лицо в танце и сейчас даже у первых балетных персонажей часто представляет полузастывшую маску с немногими трафаретными выражениями. Не то у Федоровой. Она танцует "вся". Пластически воспитанное тело очень гибко и послушно выражает замысел танца; одухотворенное лицо необычайно выразительно передает самые сложные и тонкие переживания...» [8, с. 28-29].

Многие современники утверждали, что техническое мастерство Софьи Федоровой, как и ряда других танцовщиц Горского, не было безупречным. Это мнение категорически оспаривал Григоров, считавший что неправильность ее техники - кажущаяся: артистка просто никогда не выпячивает ее на передний план, стараясь подчинить технику содержанию роли, что, на его взгляд, выгодно отличает ее не только от представителей старого «формального» балета, но и от знаменитых Екатерины Гельцер и Анны Павловой, у которых на первом плане - техника «со всеми ее придуманными премудростями, пируэтами, арабесками, аттитюдами, фуэте десятками, содержание же, смысл подгоняется к ним» [8, с. 26]. У Федоровой - «техника в ее власти, а не она в плену у техники...» [8, c. 27]. Григоров подчеркивал, что Федорова - артистка «Божьей милостью» [8, с. 25], «не “танцовщица", интересная теми или иными частными танцевальными особенностями, не балерина только, но “артист-балерина" и артистка...» $[8$, с. 21].

Мощный талант Федоровой как драматической и трагедийной актрисы был заме- 
чен в театральном мире. К.С. Станиславский в письме к сыну от 27 апреля 1907 г. шутя советовал ему открыть кафешантан, ставить там исторические пьесы в стихах. Себя он прочил на роли старых царей, а первой актрисой видел Федорову [24, с. 366-367]. Красовская утверждает, что в искусстве Федоровой «жило то сложное, что следовало бы назвать “шаляпинским", по высокому мерилу эпохи. Федорова могла быть и Кармен, и Марфой русского балета... Она олицетворила представления современников о героине трагедии...» [11, с. 159].

Вершиной творчества Федоровой считают роль жрицы Молоха в балете Горского «Саламбо» на музыку А. Арендса (1910). Григоров писал, что Федорова производит «грандиозное и яркое впечатление... Мрачная, мистически-грозная жрица в экстазе религиозного ужаса и скорби, с грозно-ужасным лицом и чародейными змеиными движениями...» [8, с. 50].

А. Шик утверждал впоследствии, что Сергей Дягилев, готовясь к первому балетному Русскому сезону в Париже, спросил известного московского режиссера А. Санина, «кого из московских балетных артистов следует пригласить... и тогда же получил от него ответ: “конечно, Софью Федорову” [30]. Так она попала в знаменитую дягилевскую антрепризу, в которой были заняты, в основном, звезды петербургского балета: Анна Павлова, Тамара Карсавина, Вацлав Нижинский, Ида Рубинштейн. Хореографом дягилевских сезонов был Михаил Фокин. «Половецкие пляски», покорившие Париж, стали легендой мировой культуры, но мало кто сегодня вспоминает, что главная заслуга в этом принадлежит Федоровой - именно она была здесь солисткой, как вспоминал русский танцовщик С.Л. Григорьев, «...танцевала половецкую девушку с потрясающим огнем» [32, с. 31].

Федорова солировала в «Вакхическом танце» («Вакханалии») на музыку А. Глазунова. По словам П.А. Ливена, она напоминала «неистовую менаду, и от ее дикого вдохновения в труппу словно вселялся бес» [33, с. 83].

Дягилев приглашал Софью Федорову и в каждый следующий Русский сезон в Париже - в 1910, 1911, 1912, 1913 гг. Вместе с его труппой она гастролировала в Берлине, Лондоне, Нью-Йорке, Брюсселе, Риме, Будапеште, Вене и везде ее талант отмечался критикой. Газета «Утро России» в июле 1910 г. опубликовала ее интервью об успехах дягилевских сезонов [18].

В течение пяти лет Софья Федорова готовила роль, ставшую для нее роковой. Горский еще в 1907 г. поставил на сцене Большого театра свою версию «Жизели» А. Адана. С 1908 г. Федорова мечтала о ней и не решалась ее исполнить. 28 апреля 1913 г. она впервые выступила в роли Жизели. Многих зрителей, привыкших видеть в балете красоту, спектакль просто испугал. В первом акте потрясала жестокой правдивостью сцена сумасшествия и смерти героини. Многие критики считали, что для балетного театра она была слишком натуралистичной. По мнению балетного критика А. Левинсона, Федорова внесла в «Жизель» «надрыв и пафос психологической драмы» [13]. Художественный критик С. Мамонтов в конечном итоге принял эту непривычную эстетику: «Первое чувство, просыпающееся в душе зрителя при виде этого страдания и этого патологически переданного безумия, заставляет воскликнуть мысленно: - Зачем такие леденящие подробности! Им нет места среди привычных балетных условностей... Но вдохновенное творчество делает свое дело... Все это так ужасно правдиво, что захватывает и вызывает нервную дрожь» [14]. Григоров утверждал, что упреки в том, что Федорова наделила свою роль чрезвычайной насыщенностью и сложностью содержания, она должна принять как «огромную похвалу» $[8$, с. 62].

Потрясало и второе действие спектакля. Горский отказался от традиционной балетной тюники и одел танцовщиц в хитоны, это было до того, как партию Жизели начала исполнять Федорова, но до нее это новшество не производило столь жуткого впечатления: она была подобна настоящей покойнице, восставшей из гроба.

Работа над спектаклем далась артистке тяжело. Во-первых, классический танец представлял для нее значительную сложность в техническом отношении. Но главное, психологически сложная роль пагубно отразилась 
на ее душевном состоянии. У хрупкой танцовщицы было слабое здоровье, с 1905 г. по болезни она нередко отказывалась от выступлений, в отдельных случаях опаздывала или даже не являлась на репетиции и спектакли, отказывалась выступать с некоторыми партнерами, о чем красноречиво свидетельствуют документы из ее личного дела, заведенного в Московской конторе императорских театров. В 1906 г. врач констатирует у нее на фоне нескольких заболеваний соматического характера общее малокровие (anaemia) [20, л. 24], в 1907 г. помимо этого - неврастению [20, л. 41].

Тем не менее, ее положение примы театра постоянно укрепляется - в 1911 г. размер ее содержания составляет 4000 рублей в год за исполнительскую деятельность и 1000 рублей в год за преподавание танцев на сцене и в театральном училище [20, л. 69].

8 октября 1913 г. на основе проведенного консилиума по поводу жалоб Федоровой на «общую физическую слабость... сильные головокружения... бессонницу... полную потерю аппетита... повышенную впечатлительность, раздражительность, скорую утомляемость и быструю резкую смену в настроении - от полной вялости и апатии с обильными слезами до повышенно бодрого живого состояния духа» врачи констатируют, что она «выглядит сильно истощенной болезнью»; ей выдается медицинское заключение, согласно которому она страдает «острым резким малокровием... общей физической нервностью...» [20, л. 124]. Консилиум пришел к выводу, что по состоянию здоровья артистке требуется освобождение от занятий балетом «на срок не менее 6 недель для курса систематического лечения в условиях санаторской обстановки...» $[20$, л. 124]. Это были признаки тяжелого нервного расстройства, которое вскоре перейдет в серьезное психическое заболевание. Софью Федорову постигла та же участь, что и других гениев балетного искусства: Вацлава Нижинского, с которым она блистала на одной сцене в дягилевской антрепризе, а впоследствии - петроградскую «красную Жизель» Ольгу Спесивцеву. Красовская считает, что Жизель Спесивцевой и Федоровой сближали «разорванное сознание и пато- логический демонизм»: «Жизели этих двух танцовщиц довели до предела и исчерпали субъективный трагизм темы»,- пишет Красовская [11, с. 313].

Федорова и Спесивцева «сломались» именно на «Жизели». Однако в воспоминаниях современников о Федоровой можно заметить свидетельства надвигающейся болезни еще до 1913 г. Так, танцовщица Бронислава Нижинская вспоминала о своем конфликте с ней, случившемся в 1911 г. Когда дягилевская труппа находилась в Монтевидео, Фокин решил поставить для нового балета «Нарцисс» танец Вакханки специально для Софьи Федоровой. Но она не приехала в Монтевидео, и роль доверили Нижинской. В июне 1911 г. Федорова приехала в Париж, где узнала, что танцевать в спектакле она не будет: «Фокин громко, на весь зал произнес: "Нижинская танцует Вакханку очень хорошо, а Софья Федорова делает совсем не то, что я хочу!" Услышав это, Федорова, еще находившаяся в партере, упала в обморок, и ее отнесли в уборную» [15, с. 134-135]. Нижинская объясняет поведение Федоровой тем, что ее «испортил» успех у зрителей: «Слава испортила ее, характер у нее был тяжелый, она легко раздражалась» $[15,135]$. Вероятно, причиной истеричности артистки была хрупкость душевной организации, которая при стечении неблагоприятных обстоятельств увлекла ее в пучину безумия.

Чувствуя, что Жизель усугубляет ее тяжелое психическое состояние, Федорова отказывается от роли и почти полностью переходит на характерные партии. Выдающаяся актриса Малого театра Елена Гоголева впоследствии вспоминала о театральных впечатлениях своей молодости, относящихся к 1913-1914 гг.: «Тогда в Большом театре блистали красавица Каралли, Балашова и моя любимица, огневая исполнительница характерных партий Федорова 2-я» [7, с. 96].

В 1916 г. Федорова выступает с номером «Пятая симфония» на музыку Бетховена, отмеченном трагической экспрессией. Однако лето 1916 г., несмотря на то, что идет война, проходит легко и беззаботно: она отдыхает в Ессентуках - в компании С. В. Рахманинова, Санина и его жены, К.С.Станиславского, 
Ф. И. Шаляпина и др. Тем не менее, события войны, революции, разруха и голод способствовали развитию болезни балерины. В сентябре 1917 г. закончился срок ее последнего контракта с дирекцией Большого театра. Она продолжала числиться в труппе, но выступала редко. Однако каждый ее выход на сцену был потрясением для зрителей, вызывал отклики. (Именно к этому времени относится цитированное выше высказывание о ней Вяч. Иванова).

В 1918 г. муж Федоровой - известный оперный певец, солист Большого театра Петр Оленин переезжает в Петроград, получив должность режиссера и управляющего оперной труппой Мариинского театра. К началу сезона 1918/19 гг. Федорова по болезни не является на службу, однако до конца 1918 г. получает жалованье в полном размере. Затем содержание было приостановлено. 16 января 1919 г. она направляет в Художественно-репертуарный Комитет Балетной труппы Государственного Большого театра заявление с просьбой назначить ей пособие для лечения «в виду тяжелых условий жизни и невозможности из-за тяжелой болезни в настоящее время служить в театре» [20, л. 150]. 7 февраля 1919 г. по запросу Комитета врач выдает свидетельство о том, что «артистка балета Федорова 2-я страдает истеро-неврологическими явлениями и вряд ли скоро может работать» [20, л. 151]. С 21 февраля согласно декрету от 21-го февраля 1919 г. ей установлен оклад в сумме 3000 рублей, представлялось 3300 рублей [20, л. 153]. В декабре 1920 г. Секретариат коллегии Наркомпроса просит Управление Московскими государственными театрами прислать подробное жизнеописание артистки Федоровой 2-й для направления в наркомсобез «на предмет исходатайствования... усиленного социального обеспечения» [20, л. 154]. Управление отправляет необходимые сведения [20, л. 155], однако, вероятно, «усиленное обеспечение» в Москве Федоровой получено не было, и она переезжает в Петроград к мужу.

28 января 1922 г. Оленин неожиданно умер. После пережитого в связи с этим стресса состояние Федоровой ухудшилось. Она уе- хала за границу - сначала в Берлин (выступив в главной роли в пантомиме «Покрывало Пьеретты» по А. Шницлеру), затем в Париж, где участвует в концертах, устраиваемых организациями русского зарубежья, дает уроки хореографии. В 1925-1926 гг. в составе труппы Анны Павловой Федорова совершает гастрольное турне по многим странам мира. В 1928 г. она вновь участвует в выступлениях дягилевской труппы, станцевав в «Половецких плясках».

Прогрессирующая болезнь оборвала ее карьеру - она была помещена в госпиталь для душевнобольных. Один из ее друзей юрист и журналист Григорий Петрович Столповский, который знал ее ещев Москве, забрал ее из лечебницы и заботился о ней до конца ее жизни. Все эти годы она находилась в состоянии «легкого безумия» и периодически лечилась в психиатрических клиниках.

Искусство балета эфемерно - даже кинопленка не сохранила следов вдохновенного творчества выдающейся балерины, ее жизни на сцене. Однако ее образ продолжает жить в произведениях трех больших мастеров русской скульптуры. Софья Федорова 2-я запечатлена в нескольких замечательных произведениях русской скульптуры: в выполненных в Москве работах Степана Дмитриевича Эрьзи («Портрет балерины Федоровой 2-й. Мрамор, 1915. Музей Государственного академического Большого театра) и Марины Давыдовны Рындзюнской («Балерина Федорова 2-я». Мрамор, 1916, ГТГ), а также в созданной в Петрограде растиражированной статуэтке Натальи Яковлевны Данько «Испанский танец». (Балерина С. В. Федорова 2-я в балете А. Глазунова «Раймонда» (фарфор, 1921. ГРМ).

Хронологически первым является скульптурный портрет, созданный Эрьзей. Работа выполнялась по заказу Большого театра. (Скульптор в это время находился в трудном материальном положении. Испытывая за границей острое чувство ностальгии, он приехал в Россию повидаться с родными, оставив свои работы и сбережения в Париже. Но началась война, и путь в Европу был закрыт. Мастер снимает мастерскую на Петровке, в подвале Высоко-Петровского монастыря и начинает работать.) 
Эрьзя изображает Федорову не на сцене, а в жизни, включив в композицию портрета (бюст с высокой линией обреза) лицо и шею артистки, создав выразительный, запоминающийся образ. Нет достоверных сведений о том, выполнялся портрет с живой модели или по фотографии (что часто бывало в практике Эрьзи). Предполагаем, что с живой модели скульптор выполнил графический портрет, оригинал которого с авторской подписью «С. Эрьзя. 1915» находится сегодня в Отделе рукописей Государственного Русского музея [16]. Скульптурный портрет выполнялся по графическому портрету и, вероятно, по ряду фотографий артистки.

Среди многочисленных фотодокументов, находящихся в личном фонде скульптора в Центральном государственном архиве Республики Мордовия есть фотография, кото-

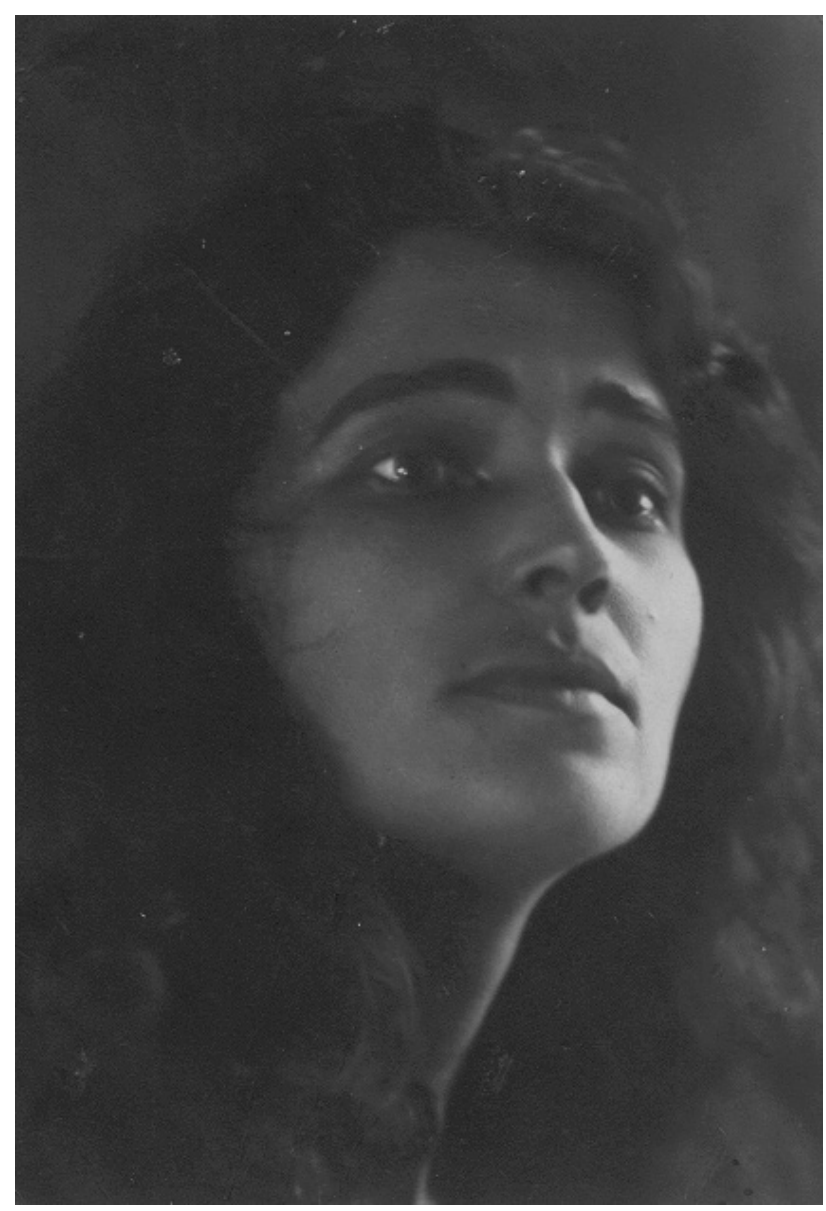

С.В. Федорова (?). Центральный государственный архив Республики Мордовия. Предварительная атрибуция И.В. Клюевой. рую мы предварительно атрибутируем как неизвестный фотопортрет Софьи Федоровой [28]. Темные густые волнистые волосы обрамляют правильный овал женского лица с необыкновенно выразительными чертами крупными и в то же время нежными. Ярко горящие темные глаза, трагедийный излом густых черных бровей... В облике молодой женщины соединены хрупкая женственность и демонизм, мягкость и жесткость, нежность и страстность, глубоко затаенная печаль и горделивый вызов, незащищенность и надменность, расслабленность и напряженность, внутренняя надломленность и цельность характера. В эрьзинском скульптурном портрете - тот же крупный нос с горбинкой, четко очерченный красивый рот, сжатый в подобие улыбки. Та же прекрасная, высокая, стройная, лебединая шея... Но волосы прикрывает модный головной убор «сетка».

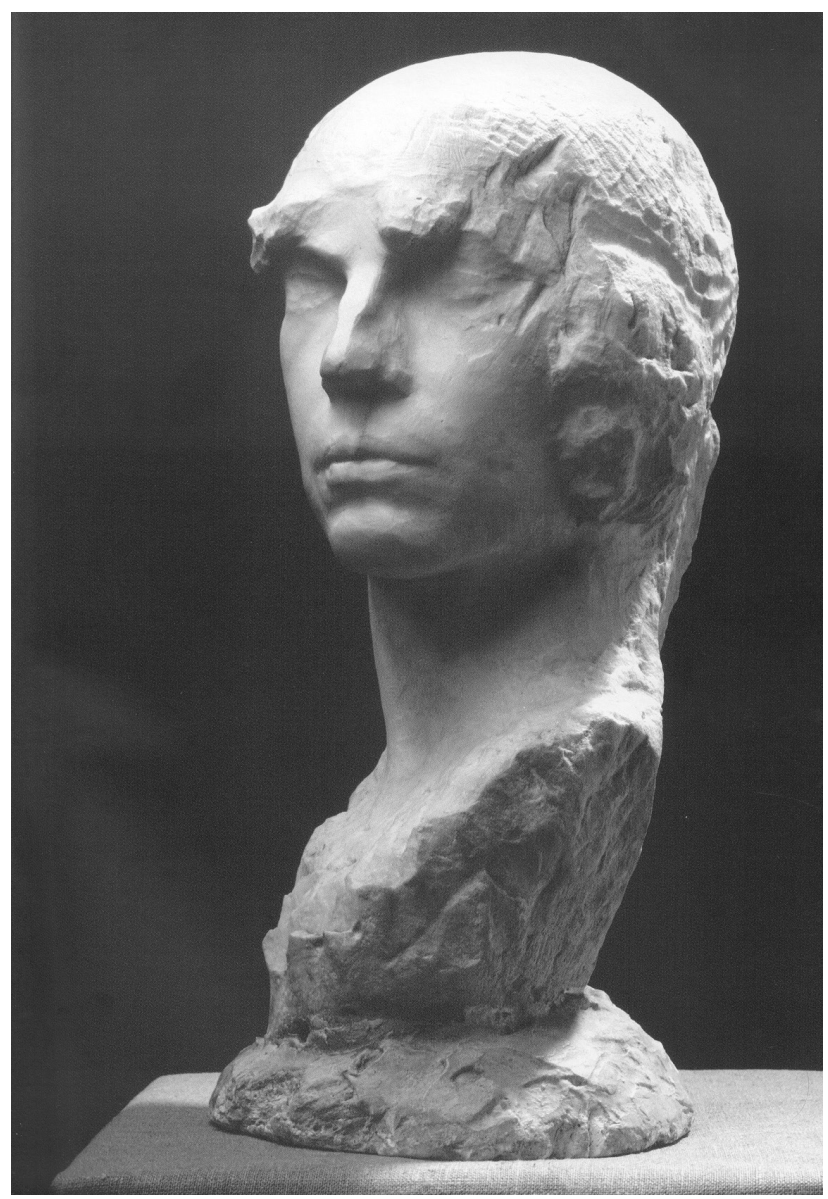

С.Д. Эрьзя. Портрет балерины С.В. Федоровой 2-й. 1915, мрамор. Музей Государственного академического Большого театра. Фотография из личного архива автора. 
Эрьзя выполняет портрет Софьи Федоровой в кульминационный момент ее творческого пути, ее судьбы. Это пик ее карьеры она недавно блистала в дягилевских антрепризах, только что вышел в свет очерк Григорова. Вместе с тем в это время она находится в состоянии глубокого душевного кризиса уже обозначены признаки разрушительной, мучительной болезни. Артистка напоминает прекрасного лебедя - гордого, но как будто испуганно встрепенувшегося, напряженно вслушивающегося в какие-то звуки - звучащие вокруг или внутри себя.

5 июня 1915 г. журнал «Русская иллюстрация» публикует статью «Степан Эрьзя» с приложением фотоснимков. На одном из них скульптор запечатлен в своей мастерской «за работой над мрамором Федоровой 2-й» [4]. В журнале помещены также фоторепродукции скульптур «Портрет Б. П. Лопатина», «Голова Христа», «Баба», «Мрамор» («Портрет

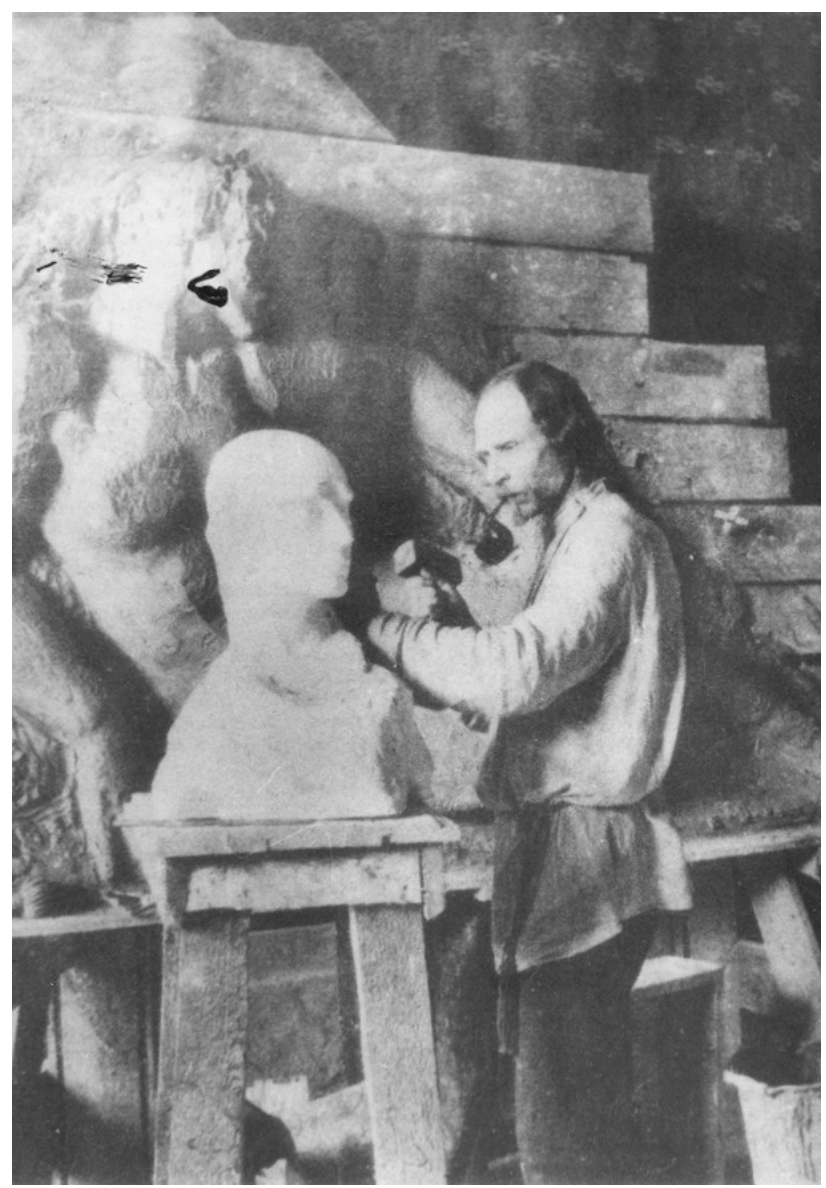

С.Д. Эрьзя за работой над портретом С.В. Федоровой. Центральный государственный архив Республики Мордовия.
Кати»). Как мы выяснили, автором статьи является известный художественный критик Б. П. Лопатин (Шуйский). Полтора месяца спустя Лопатин пишет в газете «День»: «Эрьзя, вернувшийся перед началом войны в Россию, пока осел в Москве. На досуге он начал лепить громадную фигуру женщины, в два натуральных роста. Это отвечало его склонности, в значительной степени направленной в сторону архитектурно сти. В Москве он... начал из мрамора бюст артистки С. В. Федоровой 2-й» [12].

Таким образом, одновремен-

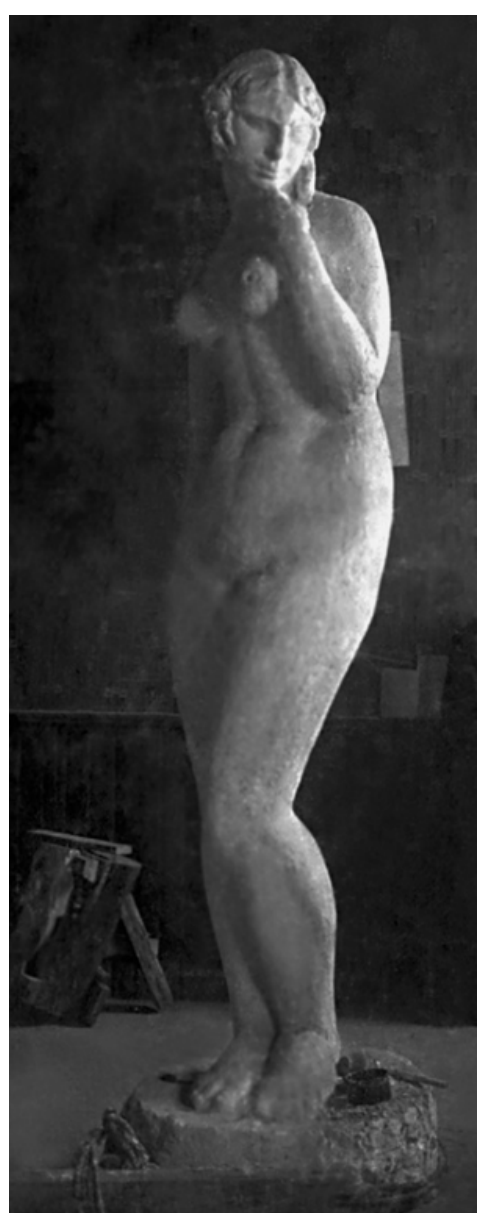

С.Д. Эрьзя. Баба (1916, цемент). Не сохранилась. Фотография. Центральный государственный архив Республики Мордовия. но с портретом

Федоровой Эрьзя работает над статуей, получившей название «Баба». Сегодня она известна по нескольким сохранившимся фотографиям. Исследователи расходятся в датировке скульптуры: М. Н. Баранова и В. С. Ионова датируют ее 1919 г., т.е. относят к уральскому периоду творчества скульптора [23, с. 429]. Сотрудники Мордовского республиканского музея изобразительных искусств им. С. Д. Эрьзи в книге, подготовленной к 130-летию со дня рождения Эрьзи - 1916 г. [17, с. 337], В. С. Дворецкая 1915 г. [25, с. 214], как и портрет Федоровой. В эрьзинских альбомах, хранящихся в Отделе рукописей ГРМ на некоторых фотографиях «Бабы» есть надпись, сделанная его рукой: «Москва 1914» (16, фотографии №№ 312, 


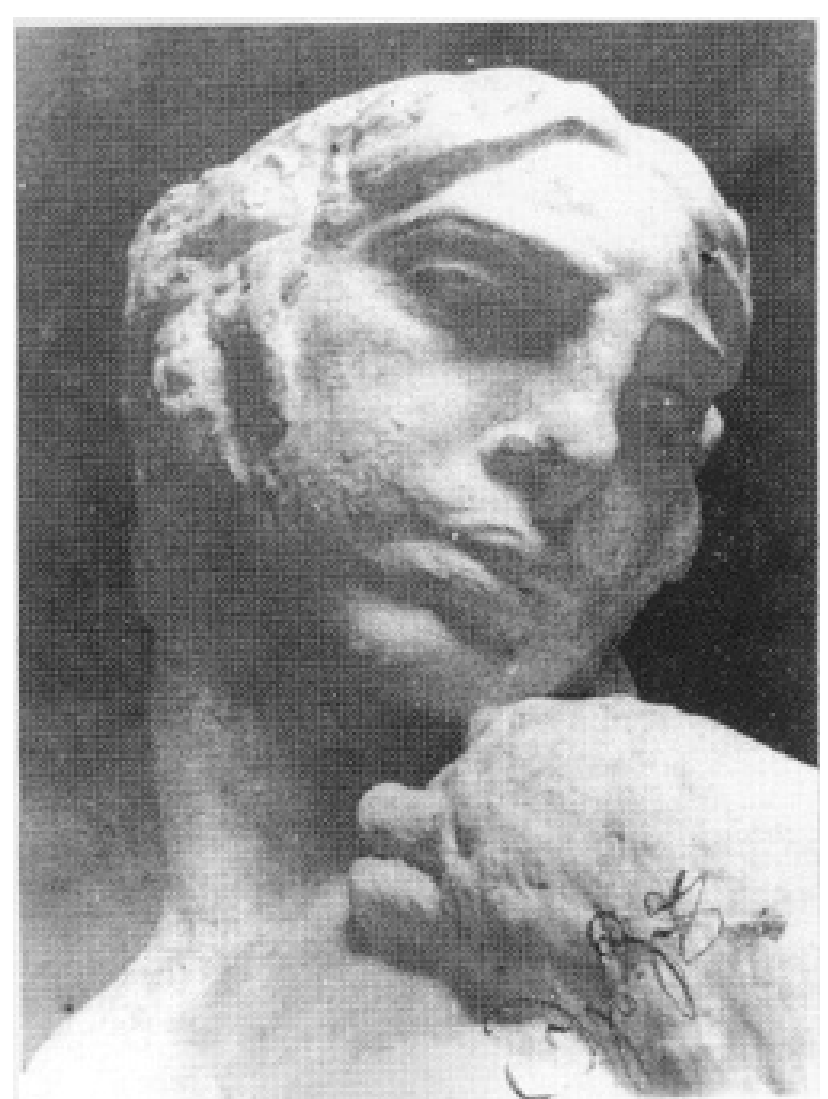

С.Д. Эрьзя. Баба (1916, цемент).

Не сохранилась. Деталь. Фотография. Центральный государственный архив Республики Мордовия.

315), в другом месте: «1915 г. Москва» [16, фотография № 204].

22 декабря 1915 г. газета «Раннее утро» публикует статью «Эрьзя в Москве»: «Маленький полутемный подвал в доме Петровского монастыря... Вот мастерская... известного русского скульптора-крестьянина, Эрьзи... Эрьзя энергично начал работать у себя в подвале. Сейчас заканчиваются несколько новых вещей, которые несомненно, явятся ценным вкладом в русское искусство» [1]. Среди этих работ называется портрет Федоровой 2-й и «Статуя женщины» (т.е. «Баба»). Следовательно, работа над портретом длилась не менее полугода: с июня или мая 1915 г. до конца 1915 г.

Сопоставив расположенные рядом на одном из листов хранящегося в ГРМ эрьзинского альбома [16] выполненный им графический портрет Федоровой 2-й и фоторепродукцию головы «Бабы», мы приходим к выводу, что это одно и то же лицо.
Это наблюдение позволяет приоткрыть завесу в тайну творчества скульптора, проследить парадоксальные метаморфозы образов, рождающихся в его художественном воображении. В данном случае лицо миниатюрной, хрупкой Федоровой соединено с мощной широкобедрой фигурой и крепкими конечностями «Бабы». Здесь в лице Федоровой нет печати демонизма, инфернальности, оно спокойно, грустно-задумчиво. Скульптор несколько изменяет форму носа, спрямляя, «антикизируя» профильную линию. Лицо балерины стало отправной точкой в свободном полете творческой фантазии скульптора, в котором была и доля шутки - судя по ряду фотографий, хранящихся в Отделе рукописей Русского музея, историко-краеведческом музее Республики Мордовия, где он запечатлен рядом с «Бабой» обнаженным.

В альбом помещены 16 фоторепродукций «Бабы» (в основном, ее лицо). Больше таких «дублей» в эрьзинских альбомах нет. Образ Федоровой, судя по всему, занимал значительное место в творческом сознании скульптора. До работы над портретом Федоровой Эрьзя крайне редко обращался непосредственно к изображению танца, хотя для его скульптур, особенно ню, были характерны своеобразные «танцующие» движения, «танцевальные» позы. На фотографии, где Эрьзя запечатлен работающим над портретом Федоровой, мы видим на заднем плане подобную фигуру - это фрагмент выполненного им барельефа для одного из особняков на Остоженке (не сохранился). Впоследствии мотив танца станет очень важным в творчестве скульптора. Вероятно, определенную роль в этом сыграла его встреча с выдающейся русской балериной. Возможно, именно о ней вспоминал мастер, хранивший много лет ее фотографию, когда работал над скульптурой «Танец», («Танцовщица», «Балерина», «Знаменитая танцовщица»), которую сам называл «Ведьма» (1929), над «Испанской танцовщицей» (1937), над другими «танцевальными» композициями.

Рындзюнская начинает работать над изображением Федоровой одновременно с Эрьзей, а возможно, даже раньше него. 
(Следует отметить, что оба скульптора ученики С. М. Волнухина - долгое время тесно общались. В 1907-1914 гг., когда Эрьзя находился в Европе, они переписывались. Ocенью 1910 г. Рындзюнская приезжала к Эрьзе в Париж, где находилась до весны 1911 г. Он выполнил несколько ее портретов в Европе и один - сразу после возвращения в Россию в 1914 г.) В апреле 1915 г. журнал «Рампа и жизнь» публикует фотографию, на которой зафиксирован один из начальных моментов работы Рындзюнской над рассматриваемым произведением. Снимок сделан в мастерской скульптора: Федорова, одетая в обычное (не сценическое) платье, стоит, держа в руках белую кружевную шаль; Рындзюнская лепит с нее модель скульптуры. Завершено произведение было лишь в 1916 г.

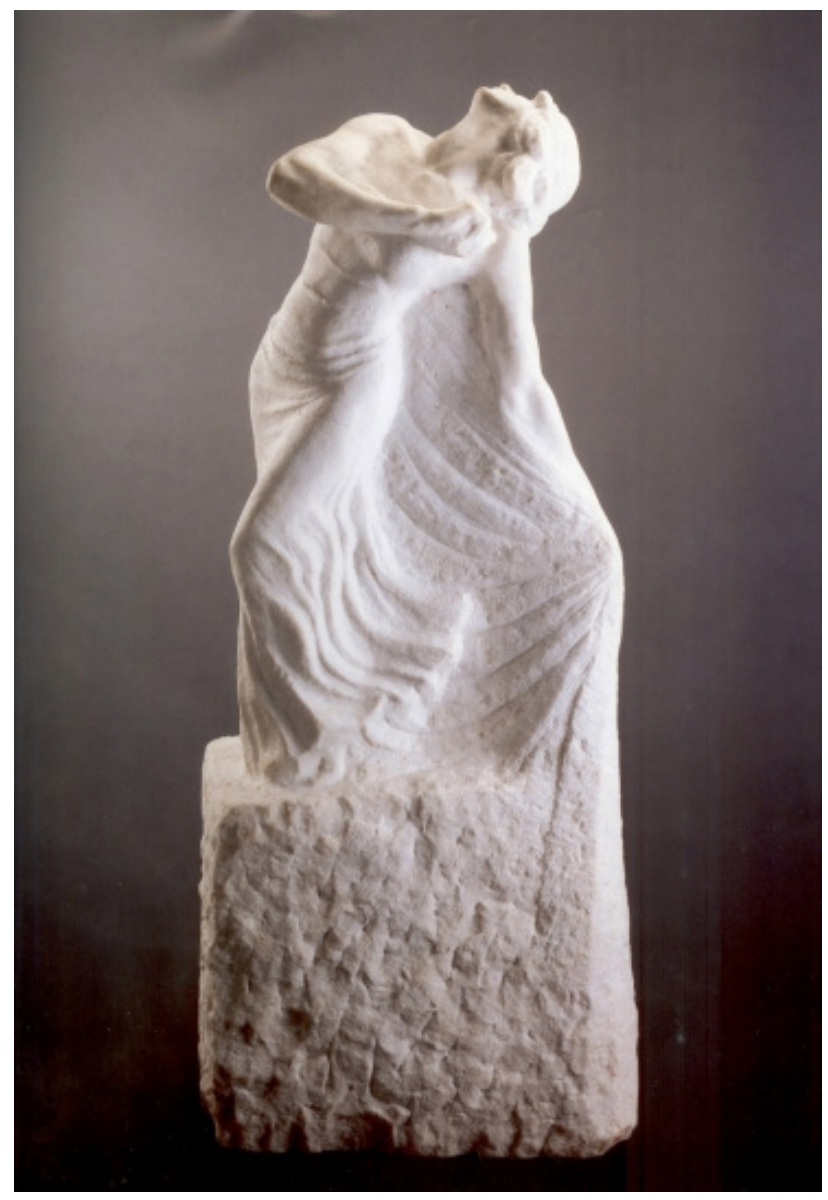

М.Д. Рындзюнская. Балерина Федорова 2-я. 1916, Мрамор. Государственная Третьяковская галерея. Фотография с официального сайта Государственной Третьяковской галереи.
Рындзюнская запечатлела Федорову не на сцене, а в жизни, но в движении - создав подлинно монументальную скульптуру, изображающую балерину во весь рост. Статуя возвышается на постаменте, голова танцовщицы сильно закинута назад - так, что лицо оказывается расположенным перпендикулярно по отношению к телу, шаль в ее руках служит своеобразной опорой в задней части скульптурной композиции. Движение фигуры развивается от напружиненного жеста прижатой к груди правой руки, приподнятого правого плеча, закинутой головы, напряженного изгиба корпуса, переходящего в линии ног (опорной правой и выдвинутой вперед левой) и заканчивается постаментом-кубом.

Т.В. Портнова, сравнивая работу Рынзюнской с «А.Дункан» С. Коненкова (1916), оценивает ее гораздо выше, поскольку в ней «движение каждой формы глубже, экспрессивность фигуры ярче, проявляется более сложная волнообразная композиция» [19, с. 68]. Исследовательница считает, что аналогией этой скульптуры в античных образцах является «Менада» Скопаса, с которой ее связывают «внешняя общность движения силуэта позы» и «выразительность мимики, богатого духовного чувства, рождаемого танцем» $[19$, с. 68].

В отличие от произведения С. Коненкова, пластическая форма у Рыдзюнской становится чеканной, весомой, силуэт тяготеет к обобщенной линии, скульптурная масса как бы имеет крепкий внутренний стержень.

Сама Рындзюнская в своих воспоминаниях утверждала, что считает «Федорову 2-ю» произведением «чисто модернистского характера» [21, л. 41], поскольку при ее создании она ставила задачу «дать в одном куске исчерпывающее движение»; впоследствии она рассматривала это как недостаток скульптуры: «И если даю это, то отношение масс не прочувствовано, не хватает архитектоники. Красоты соотношений. Эти недочеты снижают силу этой вещи, а именно ее исчерпывающее движение, вмещенное в один блок» [21, л. 51].

В конце 1916 г. Рындзюнская экспонирует эту скульптуру на выставке «Мира ис- 
кусства», о чем сообщает еще одному своему другу - скульптору Ивану Семеновичу Ефимову, находящемуся в действующей армии, на фронте: «Может, это и правильнее сейчас бросить наше искусство. Не вовремя оно. Но ничего не поделаешь - сидишь в столице, и жизнь берет свое. Выставки следуют одна за другой. И сейчас, точно не в военное время открыт “Союз", “Мир искусства" (на кот <0ром>, кстати сказать, я участвую Федоровой 2-й и большой, большой женщиной из цемента...)... Стоит и моя мраморная Федорова 2-я, не любимая мной за ее бьющий эффект, за силу движения, которая лишает ее компактной скульптурности. А вот моя старая женщина уже покойнее, скульптурнее, но, увы... публика если уж смотрит, то, конечно, на Федорову» [22, л. 1-1 об.].

Данько в фарфоровой статуэтке изображает Федорову на сцене, в характерном танце. Автор книги о Данько Ю. Эбин писал: «...Балерина представлена в порыве стремительного испанского танца. В энергичном движении она резко откинулась назад. В руке бубен. У ног - розы и брошенный веер. Бурное движение, динамика вихревого танца, выразительная пластика рук делают эту скульптуру одним из лучших произведений Данько» [31, с. 25-26]. Портнова говорит об этой работе: «Прихотливая линия очерчивает силуэт балерины, представленной в энергичном характерном танце. В красиво разработанной гамме, слагающейся из фиолетовых, красных, черных, зеленоватых цветов, звучит испанская музыка обаятельного танца» [19, с. 81$]$.

Итак, три замечательных мастера создают три совершенно разных скульптурных изображения Федоровой 2-й: монументальную мраморную фигуру (Рындзюнская), станковый мраморный бюст (Эрьзя), декоративную фарфоровую статуэтку (Данько). Данько изображает "дневную», «скачущую» Федорову, тем не менее, ей удается создать одухотворенный образ. У Рындзюнской Федорова - тоже «дневная», художницу привлекает грация балерины, выразительность ее движения, изображая которое, она сосредоточивает внимание на чисто пластических задачах. Эрьзя - единственный из трех скульпторов, сумевший увидеть и запечатлеть «ночную» Федорову. Его интересует не танец балерины, а ее сложный глубинный внутренний мир: он отражает «темную мистику» ее души (выражение Вяч. Иванова), передает охватившее женщину состояние напряжения, тревоги и беспокойства, которое не только выявляет признаки ее начинающейся душевной болезни, но и оказывается созвучным времени, когда выполнялся портрет, являясь отражением уже начавшихся и грядущих катастроф.

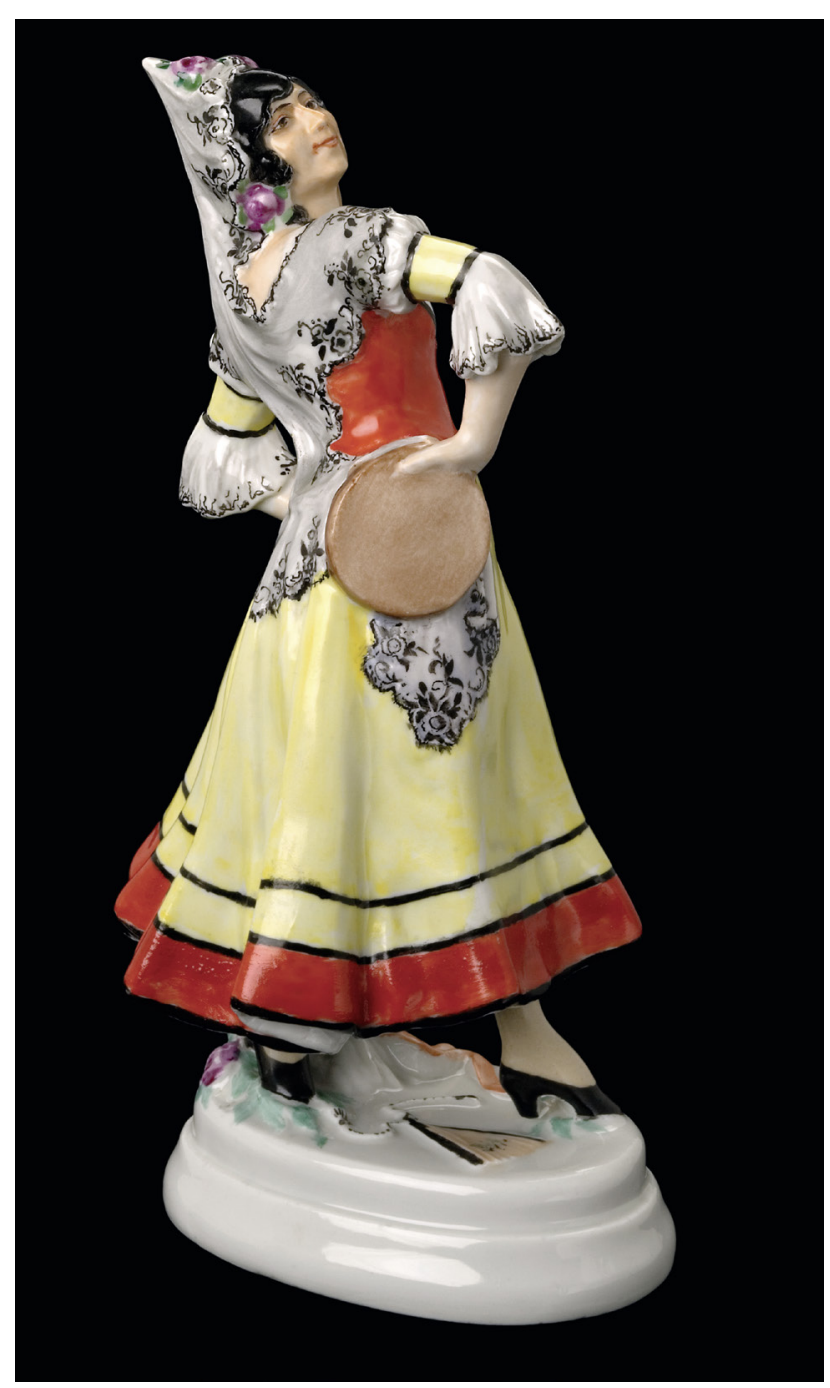

В.Ф. Рукавишникова. Испанский танец.

(Балерина С.В.Федорова 2-я

в балете А.К. Глазунова «Раймонда»).

Фарфор, 1952. (Повторение модели

Н.Я. Данько (1921). Фотография с сайта Виртуального музея

русского искусства Ю. Трайсмана. 


\section{Ballerina Sofia Fedorova II in the Russian Sculpture of the Silver Age (Stepan Erzia, Marina Ryndzyunskaya, Natalya Danko)}

Abstract. The main aim of the article is to present an art historical and cultural analysis of three portrait images of Sofia Fedorova II (1879-1963), the outstanding ballerina of the Silver Age of Russian culture, created by masters of Russian sculpture Stepan Erzia (portrait bust, 1915, marble), Marina Ryndzyunskaya (statue, 1916, marble) and Natalya Danko (figurine, 1921, porcelain). The research materials are previously unpublished documents from the archives of Moscow, Saint Petersburg, Saransk, as well as articles from Russian periodicals of the 1910s; reviews of professional critics and memories about the ballerina. Based on the use of comparative historical, biographical, and semiotic methods, the article reconstructs Fedorova's biography, considers various aspects of the reception of her personality and work by contemporaries: figures of literature (Vyacheslav Ivanov), theater (S. Giatsintova, E. Gogoleva, K. Stanislavsky, V. Telyakovsky), ballet (S. Grigoriev, B. Nizhinskaya), art critics and historians of ballet (Yu. Belyaev, P. Liven, S. Mamontov), other representatives of the humanitarian intelligentsia (S. Grigorov). Sofia Fedorova is known as an unsurpassed performer of characteristic dances in ballet and opera performances, as well as a ballerina who embodied the images of the innovative choreography of A.A. Gorsky and M.M. Fokin. Vyacheslav Ivanov claimed that the ballerina had "two faces": the "daytime", "galloping" Fedorova and the "nighttime" Fedorova, whose sphere was the "dark mysticism of the soul". The author of the article traced the history of the creation of the three sculptures and revealed their artistic features and semantic content. The three sculptors created completely different sculptural images of Fedorova: a monumental marble figure (Ryndzyunskaya), an easel marble bust (Erzia), and a decorative porcelain figurine (Danko). According to the findings of the author of the study, Danko portrays Fedorova as "daytime" and "galloping" (nevertheless, she manages to create an ethereal image). Ryndzyunskaya also shows Fedorova as "daytime", the sculptor is attracted by the ballerina's grace, the beauty and expressiveness of her movement: portraying it, she focuses on purely plastic problems. Erzia is the only sculptor of the three who managed to see and capture the "nighttime" Fedorova. He is not interested in the ballerina's dance, but in her complex deep inner world: he reflects the "dark mysticism" of her soul, conveys the state of tensity and anxiety that engulfed the woman, revealing not only signs of her incipient mental illness, but also her keen sense of the catastrophic state of the world (during World War I and the impending revolution).

Keywords: Sofia Fedorova II, Silver Age, ballet, Russian sculpture, Stepan Erzia, Marina Ryndzyunskaya, Natalya Danko.

\section{Использованная литература:}

1. Ард. А. [Ардов-Ходоровский А.]. Эрьзя в Москве // Раннее утро. 1915. 22 дек.

2. Балетмейстер А. А. Горский. Материалы. Воспоминания. Статьи. СПб.: Дмитрий Буланин, 2000.

3. Беляев Ю. Балет или каторга? // Новое время. 1902. 6 дек.

4. В. Б. Степан Эрьзя // Русская иллюстрация. 1915. 5 июня.

5. Гиацинтова С. С памятью наедине. М.: Искусство, 1985.

\section{References:}

1. Ard, A. [Ardov-Khodorovskiy, A.] (1915) Er'zya v Moskve [Erzia in Moscow]. Rannee utro. 22 December.

2. Surits, E.Ya. \& Belova, E.P. (2000) Baletmeyster A.A. Gorskiy. Materialy. Vospominaniya. Stat'i [Choreographer A.A. Gorsky. Materials Memories. Articles]. St. Petersburg: Dmitriy Bulanin.

3. Belyaev, Yu. (1902) Balet ili katorga? [Ballet or katorga?]. Novoe vremya. 6 December.

4. V.B. (1915) Stepan Er'zya [Stepan Erzia]. Russkaya illyustratsiya. 5 June. 
6. Гиацинтова С. Сцена жива женщиной // Театральная жизнь. 1960. № 9. С. 13-14.

7. Гоголева Е. На сцене и в жизни. 2-е изд., испр. и доп. М.: Искусство, 1989.

8. Григоров С. Балетное искусство и С. В. Федорова 2-я. Опыт. М.: Труд, 1914.

9. Иванов П. [Вяч. Иванов]. Заметки о балете // Театральный курьер. 1918. № 38. 30 окт.

10. Красовская В. М. Павлова. Нижинский. Ваганова. Три балетных повести. М.: Аграф, 1999.

11. Красовская В. М. Русский балетный театр начала XX века: в 2 ч. Ч. 2. Танцовщики. Л.: Искусство, 1972.

12. Л. Наши художники. III. // День. 1915. 27 июля.

13. Левинсон А. «Жизель» // Речь. 1914. 4 нояб.

14. Мамонтов С. В балете. // Русское слово. 1913. 30 апр.

15. Нижинская Б. Ранние воспоминания: в 2 ч. Ч. 2. М.: Артист. Режиссер. Театр, 1999.

16. Отдел рукописей Государственного Русского музея. Ф. 102. Оп. 1. Д. 49.

17. Папоров Ю. Н. Великий Эрьзя. Признание и трагедия: лит.-док. повесть. Степан Эрьзя: биография в документах. Саранск: [Б. и.], 2006.

18. Покой С. В. Федорова-2-я об успехах русского балета за границей. (Из беседы) // Утро России. 1910. 14 июля.

19. Портнова Т. Тема балета в русском изобразительном искусстве конца XIX - начала XX в. (проблемы интерпретации). М.: НИИ теории и истории изобразительных искусств РАХ, 1996.

20. Российский государственный архив литературы и искусства. Ф. 659. Оп. З. Д. 3796.

21. Российский государственный архив литературы и искусства. Ф. 1983. Оп. 1. Д. 11.

22. Российский государственный архив литературы и искусства. Ф. 2724. Д. 267.

23. Скульптор Эрьзя: [кн.-альбом / авт.-сост. М.Н. Баранова, В.С. Ионова]. Саранск: Мордов. кн. изд-во, 2006.

24. Станиславский К. С. Собрание сочинений: в 8 т Т. 7. М.: Искусство, 1954.

25. Степан Дмитриевич Эрьзя (1876-2001): Переписка. Статьи о творчестве. Воспоминания. Каталог произведений / сост. В.С. Дворецкая. Саранск: Мордов. кн. изд-во, 2001.

26. Суриц Е. А. А. Горский и московский балет // Балетмейстер А.А. Горский. Материалы. Воспоминания. Статьи. Спб.: Дмитрий Буланин, 2000. С. 7-72.

27. Теляковский В.А. Воспоминания. Л.-М.: Искусство, 1965.

28. Центральный государственный архив Республики Мордовия. Ф. Р-1689. Оп. 1. Д. 751.

29. Чичерин А.В. Сила поэтического слова: Статьи Воспоминания. М.: Советский писатель, 1985

30. Шик А. Памяти С.В. Федоровой 2-й // Русская мысль. 1963. 4 июня

31. Эбин Ю. Наталья Яковлевна Данько. 1892

1942. М.: Искусство, 1955.

32. Grigoriev S.L. The Diaghilev Ballet. 1909-1929. London: Penguin Books, 1960.

33. Liven P. The Birth of Ballets Russes. Boston; New York: Houghton Miffin company, 1936.
5. Giatsintova, S. (1985) S pamyat'yu naedine [Alone with memory]. Moscow: Iskusstvo.

6. Giatsintova, S. (1960) Stsena zhiva zhenshchinoy [The stage is alive with a woman on it]. Teatral'naya zhizn'. 9. pp. 13-14.

7. Gogoleva, E. (1989) Na stsene i v zhizni [On stage and in life]. 2nd ed. Moscow: Iskusstvo.

8. Grigorov, S. (1914) Baletnoe iskusstvo i S.V. Fedorova 2-ya. Opyt [Ballet art and S.V. Fedorova II. Experience]. Moscow: Trud

9. Ivanov, P. [Ivanov, Vyacheslav] (1918) Zametki o balete [Notes on ballet]. Teatral'nyy kur'er. 38. 30 October.

10. Krasovskaya, V.M. (1999) Pavlova. Nizhinskiy. Vaganova. Tri baletnykh povesti [Pavlova. Nizhinsky. Vaganova. Three ballet stories]. Moscow: Agraf.

11. Krasovskaya, V.M. (1972) Russkiy baletnyy teatr nachala XX veka: $v 2$ ch. [Russian ballet theater of the beginning of the 20th century: In 2 parts]. Pt. 2. Leningrad: Iskusstvo.

12. L. (1915) Nashi khudozhniki. III. [Our artists]. Den'. 27 July.

13. Levinson, A. (1914) "Zhizel”' [Giselle]. Rech'. 4 November

14. Mamontov, S. (1913) V balete [In the ballet]. Russkoe slovo. 30 April.

15. Nizhinskaya, B. (1999) Rannie vospominaniya: $v 2$ ch. [Early memories: In 2 parts]. Pt. 2. Moscow: Artist. Rezhisser. Teatr.

16. Manuscript Department of the State Russian Museum. Fund 102. List 1. File 49.

17. Paporov, Yu.N. (2006) Velikiy Er'zya. Priznanie $i$ tragediya: lit.-dok. povest'. Stepan Er'zya: biografiya $v$ dokumentakh [The Great Erzia. Recognition and tragedy: A literary documentary story. Stepan Erzia: biography in documents]. Saransk: [s.n.].

18. Pokoy, S.V. (1910) Fedorova-2-ya ob uspekhakh russkogo baleta za granitsey. (Iz besedy) [Fedorova II on the successes of Russian ballet abroad. (From a conversation)]. Utro Rossii. 14 July.

19. Portnova, T. (1996) Tema baleta $v$ russkom izobrazitel'nom iskusstve kontsa XIX - nachala XX v. (problemy interpretatsii) [Research Institute of Theory and History of Fine Arts of the Russian Academy of Arts]. Moscow: Research Institute of Theory and History of Fine Arts of the Russian Academy of Arts.

20. Russian State Archive of Literature and Arts. Fund 659. List 3. File 3796.

21. Russian State Archive of Literature and Arts. Fund 1983. List 1. File 11.

22. Russian State Archive of Literature and Arts. Fund 2724. List 1. File 267.

23. Baranova, M.N.\&Ionova, V.S. (2006) Skul'ptorEr'zya [The Sculptor Erzia]. An Album. Saransk: Mordov. kn. izd-vo.

24. Stanislavskiy, K.S. (1954) Sobranie sochineniy: $v 8$ t. [Collected Works: In 8 vols]. Vol. 7. Moscow: Iskusstvo.

25. Dvoretskaya, V.S. (2001) Stepan Dmitrievich Er'zya (1876-2001): Perepiska. Stat'i o tvorchestve. Vospominaniya. Katalog proizvedeniy [Stepan Erzia (1876-2001): Correspondence. Articles on oeuvre. Memories. Catalog of works]. Saransk: Mordov. kn. izd-vo.

26. Surits, E. (2000) A.A. Gorskiy i moskovskiy balet [A.A. Gorsky and Moscow ballet]. In: Surits, E.Ya. \& Belova, 
E.P. Baletmeyster A.A. Gorskiy. Materialy. Vospominaniya. Stat'i [Choreographer A.A. Gorsky. Materials Memories. Articles]. St. Petersburg: Dmitriy Bulanin. pp. 7-72.

27. Telyakovskiy, V.A. (1965) Vospominaniya [Memoirs]. Leningrad; Moscow: Iskusstvo.

28. Central State Archive of the Republic of Mordovia. Fund R-1689. List 1. File 751.

29. Chicherin, A.V. (1985) Sila poeticheskogo slova: Stat'i. Vospominaniya [The power of the poetic word: Articles. Memories]. Moscow: Sovetskiy pisatel'.

30. Shik, A. (1963) Pamyati S.V. Fedorovoy 2-y [In memory of S.V. Fedorova II]. Russkaya mysl'. 4 June.

31. Ebin, Yu. (1955) Natal'ya Yakovlevna Dan'ko. 1892-1942 [Natalya Danko. 1892-1942]. Moscow: Iskusstvo.

32. Grigoriev, S.L. (1960) The Diaghilev Ballet. 19091929. London: Penguin Books.

33. Liven, P. (1936) The Birth of Ballets Russes. Boston; New York: Houghton Miffin Company.

\section{Полная библиографическая ссылка на статью:}

Клюева И. В. Балерина Софья Федорова 2-я в русской скульптуре Серебряного века (С. Д. Эрьзя, М.Д.Рындзюнская, Н. Я. Данько) / И. В. Клюева // Наследие веков. - 2020. - № 2 - C. 117-130. DOI: 10.36343/SB.2020.22.2.011

\section{Full bibliographic reference to the article:}

Klyueva, I. V. (2020) Ballerina Sofia Fedorova II in the Russian Sculpture of the Silver Age (Stepan Erzia, Marina Ryndzyunskaya, Natalya Danko). Nasledie vekov - Heritage of Centuries. 2. pp. 117-130. (In Russian). DOI: 10.36343/SB.2020.22.2.011 